\title{
Functional drink formulation from the fermentation of banana tree (Musa parasidica) rich in antioxidant and food fibre
}

\author{
B.J. Kepel ${ }^{1}$, F. Nurkolis ${ }^{2}$, S. Kawengian ${ }^{3}$, Y. A. Assa ${ }^{3}$, N. Mayulu ${ }^{3}$, H. Natanael ${ }^{4}$ and \\ R. Rompies ${ }^{4}$ \\ ${ }^{1}$ Faculty of Medicine, Sam Ratulangi University, Kampus Unsrat Bahu Street, Manado, Indonesia, \\ ${ }^{2}$ Department of Biological Sciences, Faculty of Sciences and Technology, State Islamic University of Sunan Kalijaga, \\ Indonesia, \\ ${ }^{3}$ Food and Nutrition Department of Sam Ratulangi University, Kampus Unsrat Bahu Street, Indonesia and \\ ${ }^{4}$ Department of Pediatrics, Sam Ratulangi University/Prof.dr.R.D.Kandou Hospital Manado, Raya Tanawangko 56 \\ street, Manado, Indonesia
}

Banana tree (Musa parasidica) is an environmental waste that can be extracted from starch and used as an innovative product high in food fibre and potential probiotics by adding pineapple pulp (Ananas comosus) ${ }^{(1)}$. This study aims to process or formulate and utilize Banana Tree Starch with the addition of pineapple pulp into a functional food product in the form of probiotic drinks. In addition, in vitro levels of antioxidants (especially vitamin C) and total dietary fibre were also carried out.

There are 3 variations of the formulation, Banana Tree Starch: Pineapple: CO2 free water. Sample 1 (1: 0.5: 0.5), sample 2 (2: 1: 1) and sample 3 (3:2:2). Then, all product samples were inoculated with Lactobacillus paracasei for 60 hours and incubated in anaerobic conditions with a temperature of $30-32^{\circ} \mathrm{C}$. Sample variation was carried out to determine the significance of the average antioxidant content in it. The next step is to test the analysis of vitamin $\mathrm{C}$ from 3 variants of beverage samples using the Iodometric Titration Method, to determine the amount of Vitamin $\mathrm{C}(\mathrm{mg} / 100 \mathrm{~g})$ and the antioxidant activity with 2.2-diphenyl-1-picrylhydrazyl (DPPH). Determination of dietary fibre content using the AOAC method. All with triple repeat per sample.

The amount of vitamin C obtained at S1 was $80.45 \pm 0.05 \mathrm{mg} / 100 \mathrm{~g}$ with $44.95 \pm 0.99 \%$ antioxidant activity and $11.01 \pm 0.01 \%$ dietary fibre. S2 respectively $65.75 \pm 0.05 \mathrm{mg} / 100 \mathrm{~g}$ with antioxidant activity of $30.60 \pm 0.30 \%$ and $8.90 \pm 0.10 \%$ dietary fibre. S3 was $47.02 \pm 0.02$ $\mathrm{mg} / 100 \mathrm{~g}$ with $32.10 \pm 0.20 \%$ antioxidant activity and $7.89 \pm 0.10 \%$ dietary fibre. The fermented drink sample formulation containing the highest vitamin $\mathrm{C}$ was $\mathrm{S}$. There was a significant difference $(\mathrm{P}<0.05)$ which determined the vitamin $\mathrm{C}$ levels between the sample formulations. The average ash content of the three samples was $4.77 \pm 0.07 \%$ and the moisture content was $37.72 \pm 7.72 \%$. The average vitamin $\mathrm{C}$ level in the three fermented drink samples was $64.40 \pm 16.75 \mathrm{mg} / 100 \mathrm{~g}$. S1 showed the best activity, namely the antioxidant activity against 2.2-diphenyl-1-picrylhydrazyl (DPPH) of $44.95 \pm 0.99 \%$ and also had high levels of dietary fibre and high vitamin C.

The formulation of a combination of banana tree starch with the addition of pineapple pulp has great potential to be developed into a health functional food. By looking at the content of vitamin $\mathrm{C}$ and total dietary fibre and antioxidants in the fermented products, this can be an effort to diversify local food and can be an alternative to anti-diabetic drinks and other infectious diseases ${ }^{(2)}$.

\section{Acknowledgements}

This funding is research from first author and we thank all of the contributors for their outstanding help in formatting the abstract. The authors' responsibilities were as follows - all authors: contributed to the writing and revisions contained in the abstract; and all authors have read and approved the final abstract.

\section{References}

1. Setianingsih, R. (2020). (Doctoral dissertation, UIN Raden Intan Lampung).

2. Jayedi A, Rashidy-Pour A, Parohan M, et al. (2018) Adv Nutr, 9(6), 701-716.

3. Jiao J, Xu JY, Zhang W, et al. (2015). Int J Food Sci Nutr, 66(1), 114-119. 